important problem. There were no large claims : the responsibility for selection must lie fairly on the shoulders of the employer. But by dispelling false ideas as to the necessity of elaborate techniques, the discussion showed how the psychologist could clarify ideas and simplify the process; thereby assisting in making the selection process acceptable to all concerned, because it filled the proviso that was allimportant in the field of officer selection during the War-that so far as possible justice was done.

\section{AMERICAN AWARDS TO BRITISH MEN OF SCIENCE}

$\mathrm{T}$ Nature of May 17, p. 684, a list was given of 1 awards of the Medal of Merit, the highest award made by the Government of the United States to a civilian, to eight leading men of science in Britain, for services during the War. Recently thirty-two other British subjects received decorations for their work; the list includes the following names of scientific men, with a brief statement indicating the grounds of the award:

\section{Medal of Freedom, with Silver Palm}

Dr. H. J. Gough, director-general of scientific research and development in the Ministry of Supply;

Prof. A. V. Hill, for exceptionally meritorious service in the field of scientific research and development ;

Sir Frank Smith, controller of telecommunications equipment in the Ministry of Aircraft Production and chairman of the Scientific Advisory Council of Ministry of Supply ;

Dr. R. L. Smith-Rose, for scientific investigations which laid the groundwork for important developments in the field of radio propagation.

\section{Medal of Freedom, with Bronze Palm}

Prof. J. D. Bernal (University of London), for meritorious service in the field of scientific research and development; and in assessing bomb damage;

Dr. Henry G. Booker (University of Cambridge), head of the Mathematics Section at the Telecommunications Research Establishment of the Ministry of Aireraft Production ;

Mr. A. Lang Brown, Department of Scientific Research and Experiments (Admiralty), and secretary of the Admiralty Committee on Infra-Red Research ;

Mr. S. J. Grose (Ministry of Supply), secretary of the British Counter Measures Board;

Dr. Hubert G. Hopkins (Radio Division, National Physical Laboratory), for meritorious service in the field of scientific research and development, working in the field of radio ;

Dr. E. Talbot Paris, physicist in the Ministry of Supply, responsible for development of radar communications and other electronic equipment;

Dr. William J. Richards (Telecommunications Research Establishment), deputy director of scientific research in the Ministry of Aircraft Production, concerned with aerial warfare and guided missiles;

Mr. William Ross, for meritorious service as physicist in the field of radio and radar;

Mr. John M. C. Scott, physicist working on radio propagation, member of the Radar Research Development Establishment and secretary of the Ultra-Short Wave Propagation Panel of the Ministry of Supply.

\section{Medal of Freedom}

Mr. W. G. Busbridge (Chemical Defence Experimental Station, Porton, Wilts), for meritorious service in the field of scientific development, chemical warfare ;

Mr. W. J. Challens (Ministry of Supply), for important comprehensive investigations in relation to rockets ;

Prof. C. N. Hinshelwood (University of Oxford), for meritorious service in the field of scientific development and for successful research in gas-mask absorbents.

\section{Bronze Star Medal}

Captain B. R. S. Dalton, in charge of orientation and training in photo interpretation, Photo Intelligence Centre, Military Intelligence Service, December 1943-June 1944 ;

Lieut.-Colonel H. F. Jones, for his work on the basic investigation and planning for new types of fuels for use in the British Army, September 1942May 1945.

Medal for Merit

Dr. R. V. Jones (Department of Natural Philosophy, University of Aberdeen), for outstanding service to the United Nations during 1939-45; assistant director of intelligence (science) at the British Air Ministry.

\section{THE FACTUAL FILM}

$T$ $\mathrm{HE}$ second of four reports to be presented by the Dartington Hall Trustees on the Visual Arts, the Factual Film, Music and the Theatre has recently been published*. The work of the Arts Enquiry, which was established in 1941, the reports are designed to give an account of the place of these arts in the national life, their economic and administrative background, their social importance and their value in general education. As the statement that "the documentary is Britain's outstanding contribution to the film" may be regarded as one of fact rather than of opinion, it is only right that a study of the British documentary film should have been included in this series.

Important as are the historical sections-and more especially those which trace the early development of documentary films under the direction of John Grierson at the Empire Marketing Board and the General Post Office, the effect of war-time demands for films for training purposes, and the evolution of the educational film - chief interest centres around the comments, criticisms and recommendations which the authors have incorporated. The work of the Film Division of the Ministry of Information and the film activities of the British Council are assessed. The trivial content of many news-reels is criticized. The case for a more systematic preservation of films for record purposes is presented. The necessity for the training of teachers in the use of films is stressed. The activities of the British Film Institute are held to be unsatisfactory on account of weaknesses in its constitution, organisation and methods of finance"though these cannot be held wholly responsible for the lack of initiative and drive characteristic of much of its work".

It says much for both the foresight and insight of those responsible for this report that three of the four

* The Factual Film: a Report published on behalf of the Arts Enquiry by P.E.P. (Political and Economic Planning) Pp. 260. (Oxford University Press ; Geoffrey Cumberlege, 1947.) 128. $6 d$. net. 
recommendations made-the continuance of the Film Division of the Ministry of Information, the development of an educational film policy by the Ministry of Education, and the establishment of a film depart. ment within the United Nations Educational, Scientific and Cultural Organisation-were accepted in principle in the interval between the completion of the text and the date of publication. The demand that the British Film Institute should be reconstituted is, perhaps, more controversial ; but, in the light of conclusions reached in this report, there is much to be said in favour of an impartial investigation of its activities.

\section{FORTHCOMING EVENTS}

(Meetings marked with an asterisk* are open to the public)

\section{Saturday, October II}

INSTITUTION OF ChEMical ENGINEERS, NORTH-WESTERN BRANCH (in the Reynolds Hall, College of Technology, Manchester), at 3 p.m.-" Monday, October 13

Manchrster LITERARY AND PhLlosophical Society (in the Reynolds Hall, College of Technology, Manchester), at 5.30 p.m.-
Dr. H. L. Rose: "New Anti-malarial Drugs"."

Tuesday, October 14

BRITISH SOCIETY FOR INTERNATIONAL BIBLIOGRAPHY (at the Institution of Electrical Engineers, Savoy Place, Victoria Embankment, London, W.C.2), at 2.30 p.m.-Papers.

ZOOLOGICAL SOCIETY OF LONDON (at Regent's Park, London, N.W.8), at 5 p.m.-Scientiflc Papers.

INSTITUTION OF CHEMICAI ENGINEFrs (at the Institution of Mechanical Engineers, Storey's Gate, St. James's Park, London, S.W.1), at 5.30 p.m.-Dr. R. V. Southwell, F.R.S.: "Relaxation Methods, a

ILLOMNATING ENGINERRING SocreTX (at the London School of Hygiene and Tropical Medicine, Keppel Street, London, W.C.1), at 6 p.m.-Dr. .T. W. T. Walsh : Presidential Address.

\section{Wednesday, October 15}

GEOLOGICAL SOCTETY OF LONDON (at Burlington House, Picçadilly, London, W.1), at 5 p.m. Prof. F. A. Vening Meinesz : "Major Tectonic Phenomena and the Hypothesis
the Earth" (Third William Smith Lecture).

INSTTTUTION OF ELEOTRICAL ENGINEERS, RADIO SECTION (at Savoy Place, Victoria Embankment, London, W.C.2), at 5.30 p.m.-Mr. C. E. Strong: Inaugural Address as Chairman.

SOCIETY OF ChEMTCAL INDUSTRY, NEWCASTIE SECTTON (joint meeting with the BRITISH RHEOLOGISTS' CLUB and the OIL AND COLOUR CHEMISTS' ASSOCIATION, in the Chemistry Lecture Theatre, King's
College, Newcastle-upon-Tyne), at 5.30 p.m. - Symposium on "EnnulCollege, Newcastle-upon-T
sions, Dopes and Paints".

Manchester Metalduraioal Societr (at the Engineers" Club, Albert Square, Manchester), at 6.30 p.m.-Dr. L. C. Bannister :

BRITTSH PSYCHOLOGIOAL SOCIETY INDTSTRIAL STCTTON (at the London School of Hygiene and Tropical Medicine, Keppel Street, London, W.C.1), at 7 p.m.-Mr. B. Ungerson: "Personnel Selection in the British Army (other Ranks)".

\section{Thursday, October 16}

Instutution of Mining AND Metalltergy (at the Geological Society, Burlington House, Piccadilly, London, W.1), at 5 p.m.Papers.

LINNEAN SOCIETY OF LONDON (at Burlington House, Piccadilly, London, W.1), at 5 p.m.--Dr. E. M. Delf : "Utilization of Seaweeds"' Dr. M. Burton :

London Mathematicar Society (at Burlington House, Piccadilly, London, W.1), at 5 p.m.-Lecture by Prof. I. E. J. Brouwer.

INSTITUTION OF ELECTRICAT ENGINERRS, INSTALLATIONS SECTION (at Sa voy Place, Victoria Embankment, London, W.C.2), at 5.30 p.m. Mr. R. H. Rawll : Inaugural Address as Chairman.

TEXTILE INSTITUTE, LANCASHIRE SECTION (at 16 St. Mary's Parsonage, Manchester), at $6.30 \mathrm{p} . \mathrm{m} .-\mathrm{Mr}$. P. P."
Studies of Labour Utillsation in Spinning".

CHEMTCal Soctetry (joint meeting with the Local SEctions of the ROYAL INSTITUTE OF CHEMISTRY and the SOCIETY OF CHEMICAI INDUSTRY, at the North British Station Hotel, Edinburgh), at 7.30 p.m. INDUSTRY, at the North British Station Hotel, Edinbur.

ROYAL SOCIETY OF TROPICAL MEDICINE AND HYGIENE (at Manson House, 26 Portland Place, London, W.1), at 7.30 p.m.-. Sir Philip
Manson-Bahr : "The Practice of "Tropical Medicine in London" Manson-Bahr
(Presidential Address).

\section{Friday, October 17}

UNIVERSTTIES FEDERATION FOR ANIMAL W ELFARE (in the Anatomy Theatre, University College of London, Gower Street, London, W.C.1) at 5.15 p.m.-Dr. Harry R. Lillie: "Whaling To-day-the Search for a Humane Method of Killing".
INSTITUTION OF ELECTRICAL ENGINEERS, MEASUREMENTS SECTTON (at Savoy Place, Victoria Embankment, London, W.C.2), at 5.30 p.m. -Mr. D. C. Gall : Inaugural Address as Chairman.

ROYAL INSTTTUTE OF CHEMTSTRY, LONDON AND SOUTH-EASTERN COUNTIES SECTTON (at the Geological Society, Burlington House, Applications of Acetylenic Compounds in Organic Synthesis" (Meldola Medal Lecture).

NORTH-EAST COAST INSTITUTION OF GNGINERRS AND SHIPBUILDERS (at the Literary and Philosophical Society, Newcastle-upon-'Tyne), at 6.15 p.m.-Annual General Meeting; Mr. H. B. Robin Rowell : Presidential Address.

\section{APPOINTMENTS VACANT}

ApPLications are invited for the following appointments on or before the dates mentioned

ASsisTANT LECTURER IN DYEING in the Bradford Technical College The Director of Education, Town Hall, Bradford (October 18). JUNIOR ASSISTANT PHYSICIST at the Radiotherapy Centre, Scun-
horpe-The Olerk, Lincolnghire Joint Cancer Committec, County

thorpe-The Olerk, Lincolnsh
Offices, Lincoln (October 18).

GRADUATE ASSISTANT IN THE DEPARTMENT OF BIOCHEMTSTRYThe Administrator, Radcliffe Inflrmary, Oxford (October 18).

ASSISTANT LECTURER (male) IN AGRICULTURE-The Principal, Yorkshire Institute of Agriculture, Askham Bryan, York (October 18).
IAECTURER IN PHYSICS-The Principal, Chelsea Polytechnic, Manresa LECTURER IN PHYSICS-The Princis

RESPONSIBLE LECTURER IN DEPARTMENT OF EJEOTRICAL ENGINEERING AND ENGINEERING MATHEMATICS, and a SENIOR ASSISTANT in charge of DEPARTMENT OF GENERAL SCIENCE AND RELATED MATHEMatrCS-The Principal, Aston Technical College, Whitehead Road, Birmingham 6 (October 18).

LECTURER IN ELECTRICAI ENGINEERING at the Rutherford College of Technology - The Director of Education, City Education Office, Northumberland Road, Newcastle-upon-Tyme 1 (October 18).

PRINCTPAL OF THE RUGBY COLLEGE OF TECHNOLOGY AND ARTS-
The The

LECTURER (Grade II) IN THE DEPARTMENT OF MRCHANICAT

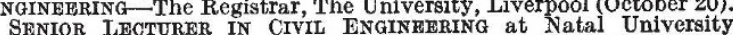
College, Durban-The Secretary, Universities Bureau of the British Empire, 8 Park Street, London, W.1 (November 17).

SENIOR LEOTURER IN MATHEMATICS, a SENIOR LECTURER or LECTURER IN CHEMISTRY, a SENIOR LECTURER OI LECTURER IN ZOOLOGY, a LECTURER (man) IN BOTANY (Plant Physiology), a LECTURER IN CHEMISTRY (Inorganic), a LECTURER IN CHEMISTRY (Organic), LIECTURFRS (2) IN APPLIED MATHHEMATTCS, LECTURRRS (2) IN PURE MATHEMATIOS, LECTURERS (2) IN ELECTRICAL ENGINERRING, LECTURERS (2) IN MECHANICAL ENGINEERING, a WORKSHOP ASSISTANT IN CIVIL ENGINEERING, a WORKSHOP ASSISTANT IN ELECTRIOAL ENGINEERING, a LECTURER IN SOCTAL ANTHROPOLOGY, a LECTURER IN NATIVE ADMINISTRATION, and a LECTURER IN AGRICULTURAL ECONomics, at Natal University College, Pietermaritzburg - The Secretary, Universities Burea

IECTURER IN BOTANY at the University of Cape Town-The Secretary, Universities Bureau of the British Empire, 8 Park Street, London, W.1 (November 30).

Director of THE NATAL MUSium-The High Commissioner for South Africa, Trafalgar Square, London, w.C.2 (Pietermaritzburg, November 30 ).

SENIOR IECTURER IN PHYsios at Auckland University College, Auckland, New Zealand-The Secretary, Universities Bureau of the British Empire, 8 Park Street, London, W.1 (December 1).

ECONOMTC ENTOMOLOGIST and an ENTOMOLOGIST for research (particularly on control) and general survey of all insect life of the country, and an ENTOMOLOGIST for work in Plant Protection Division on general applied entomology and pest control (not research), to the Directorate-General of Agriculture, Iraq-The Crown Agents

SCIENTIFIC OFFICER for work in connexion with iron and steelmaking refractories and an ASSISTANT CIVIL AND STRUOTURAL ENGINEER by the Plant Fingineering Division to assist in applied research-The Personnel Officer, British Iron and Steel Research Association, 11 Park Lane, London, W.1.

SENIOR TECHNICAL OFFIOER to undertake and supervise research on Wool and Fur fibres, a TECHNICAL OFFICER to carry out research work in collaboration with the Senior Technical Officer, and an NTELLIGENCE OFFICER to take charge of Library and Records Section -The Secretary, British Hat and Allied Feltmakers' Research Association, 12 St. Peter's Square, Stockport, Cheshire.

B - The Registrar, Wye College, Wye, Ashford, Kent.

INSPEOTORS or MiNEs in Nigeria-The Director of Recruitment, Colonial Service, 15 Victoria Street, London, S.W.1.

IfeTURar iN Mrohanical Engineming-The Principal, Bedford Technical Institute, Midland Road, Bedford.

SRNIOR ASSISTANT LECTURER IN EIECTRICAT ENGINERRING at Darlington Technical College-The Chief Education Officer, Education Office, Darlington.

Assich Junior Technical School-The Principal, Forest of Dean Mining and Technical School, Cinderford, Glos.

LRCTURER IN PHYsICs-The Principal, Sir John Cass Technical Institute, Jewry Street, Aldgate, London, E.C.3.

IECTURER IN MEOHANIOAL ENGINEERING - The Director of Educaion, The Polytechnic, 309 Regent Street, London, W.1.

ASSISTANT MASTER FOR ENGINEERING SCIENCE, to take charge of a well-equipped Physics Laboratory at the Central Technical SchoolThe Director of Education, Education Office, Sheffield 1.

LEOTURER IN BIOLOGY with special knowledge of Zoology, and a LECTURER IN MECHANICAL ENGINEDRING-The Principal, West Ham
Municipal College, Romford Road, Stratford, London, E.15. 